\title{
Analisis Pengelolaan Penjualan Penyambung (Entres) Kopi Berdasarkan Penerapan Social Oriented, Kebun Induk Kopi Robusta, Desa Sai, Kecamatan Pupuan
}

Luh Gede Kusuma Dewi ${ }^{\mathrm{a}}$, Umbu Joka ${ }^{\mathrm{b}}$

${ }^{a}$ Fakultas Ekonomi Universitas Pendidikan Ganesha, Singaraja - Provinsi Bali, Indonesia. Email :kusumadewi5758@gmail.com

${ }^{b}$ Fakultas Pertanian, Universitas Timor, Kefamenanu - TTU, Provinsi NTT, Indonesia. Email :umbujoka@unimor.ac.id

\section{Article Info}

\section{Article history:}

Received 10 Februari 2020

Received in revised form 23 Februari 2020 Accepted 15 Maret 2020

https://doi.org/10.32938/ag.v5i2.1011

\section{Keywords:}

Penjualan

Petani Kopi

Berorientasi Sosial

\section{Abstrak}

Penelitian ini bertujuan untuk : 1) Untuk mengetahui latar belakang Kebun Induk Kopi Robusta, Desa Sai, Kecamatan Pupuan melakukan penjualan penyambung kopi berdasarkan penerapan Social Oriented;2) Untuk mengetahui karakteristik dan keunggulan Kebun Induk Kopi Robusta; dan 3) Untuk mengetahui apakah penjualan penyambung kopi dapat mencapai social oriented pada aktifitas operasi Kebun Induk Kopi Robusta, Desa Sai, Kecamatan Pupuan. Jenis penelitian yang digunakan adalah penelitian kualitatif dengan subyek penelitiannya yaitu Kepala UPT Dinas Pertanian Holtikultura dan Staf di Kebun Induk Kopi Robusta. Data yang diperoleh dalam penelitian ini dikumpulkan melalui wawancara, observasi, dokumentasi dan studi pustaka. Hasil dari penelitian ini menunjukkan: 1) Latar belakang penjualan penyambung (Entres) Kopi pada Kebun Induk Kopi adalah untuk menyediakan entres kopi yang digunakan oleh petani dalam merevitalisasi tanaman kopinya yang sudah tidak produktif; 2) Karakteristik dan keunggulan penerapan Social oriented untuk meningkatkan kehidupan sosial masyarakat sehingga dapat meningkatkan kesejahteraan hidup melalui kegiatan pertanian kopi; Dan 3) penjualan Entres Kopi Berbasis Social oriented pada aktifitas operasi Kebun Induk Kopi Robusta adalah dengan mematok harga jual menjadi dua yaitu khusus petani kopi rakyat dengan harga Rp250/ruas dan kegiatan proyek/Lembaga Ekonomi Masyarakat dengan harga Rp750/ruas.

\section{Pendahuluan}

Kemajuan dunia usaha di sektor pertanian dewasa ini semakin berkembang dengan pesat, baik dalam skala besar maupun kecil. Salah satu tujuan dari suatu usaha adalah untuk menghasilkan laba, yang mana dari laba ini akan digunakan untuk mengembangkan sumber daya dari unit usaha tersebut. Sehingga tujuan dari sebuah perusahaan atau kelompok usaha mampu dicapai.Hasil survei Badan Pusat Statistik (BPS) terkait pertumbuhan ekonom Triwulan II Tahun 2018 yang menyatakan kontribusi pertanian pada laju pertumbuhan Produk Domestik Bruto (PDB) mencapai 13,63\%. Fakta tersebut mengindikasikan bahwa sektor pertanian merupakan salah satu penggerak utama dalam pengembangan ekonomi rakyat Indonesia(www.pertanian.go.id).Sektor pertanian sendiri memiliki beberapa subsektor, antara lain tanaman pangan, perkebunan, peternakan, kehutanan, serta perikanan. Indonesia merupakan salah satu negara yang cocok untuk subsektor perkebunan, karena pada umumnya perkebunan berada di daerah bermusim panas atau di daerah sekitar khatulistiwa (Permatasari, 2014).

Kopi merupakan salah satu komoditi perkebunan yang penting dalam perekonomian nasional. Hal ini terlihat dari peran sektor perkebunan kop terhadap penyediaan tenaga kerja, penyedia devisa negara melalui ekspor (Nopriyandi dan Haryadi, 2017).Total ekspor kopi delapan tahun terakhir cenderung berfluktuasi (lihat Gambar 1)

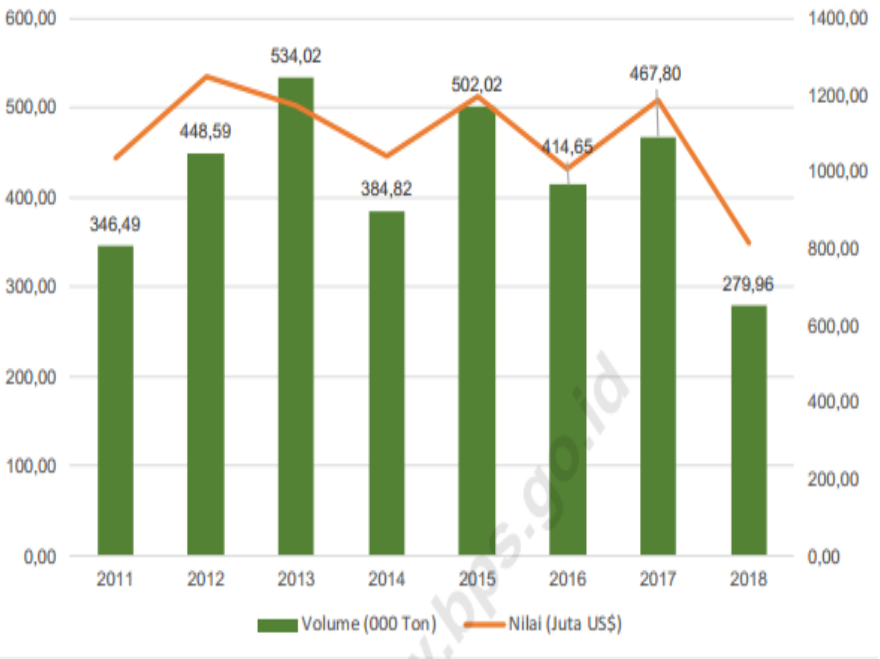

Gambar 1. Perkembangan Volume dan Nilai Ekspor Kopi 2011 -2018 ( BPS, 2019)

Berdasarkan informasi dari situs https://kemenperin.go.id, penurunan jumlah ekspor kopi dari Indonesia dipengaruhi oleh penurunan jumlah produksi kopi. Menurut Retnandari dan Tjokrowinoto dalam Karo (2009), penurunan produksi kopi bisa disebabkan karena umur tanaman kopi yang sudah cukup tua Hal ini senada dengan hasil penelitian dari Nalurita dkk (2014) yang mengungkapkan bahwa tingkat produktivitas kopi Indonesia lebih rendah dari negara lainnya (Brazil, Kolombia, dan Vietnam) disebabkan karena 95\% kopi Indonesia merupakan perkebunan rakyat yang umumnya belum menggunakan bibit kopi unggul, teknik budidaya yang masih sederhana serta lambat melakukan peremajaan tanaman, minimnya sarana dan prasarana pendukung mengakibatkan rendahnya mutu kopi Indonesia. Dari kedua penelitian tersebut disebutkan bahwa salah satu cara untuk menanggulangi permasalahan ini adalah dengan cara merehabilitasi tanaman kopi yang tidak produktif lagi dan meningkatkan pemeliharaan kopi tersebut secara intensif. Dengan demikian peran kopi tetap dapat dipertahankan dan diharapkan dapat meningkatkan pendapatan nasional, mengingat kopi merupakan salah satu komoditi ekspor yang unggul. Nopriyandi (2017) menyebutkan bahwa diharapkan adanya strategi pengembangan agribisnis kopi lokal di Indonesia yang dapat dilakukan meliputi peningkatan produksi kopi lokal, baik terhadap kualitas maupun terhadap kuantitas agar komoditi kopi Indonesia bisa lebih unggul di pasar Internasional

Provinsi Bali memiliki area yang ditanami perkebunan kopi seluas 35.232 Ha dan total produksi hingga 13.578 ton. Salah satu kecamatan yang memproduksi kopi adalah di Kecamatan Pupuan. Desa Sai merupakan salah satu desa di Kecamatan Pupuan yang hampir semua masyarakat desa memberdayakan diri sebagai petani kopi.Hasil pertanian di Desa tersebut juga sangat baik dan berkualitas, sehingga Desa Sai dijadikan contoh perkebunan kopi yang disebut Kebun Induk Kopi Robusta.Petani kopi di Desa Sai telah menerapkan tekologi budidaya kopi sambung untuk meningkatkan produksi kopi.Sebelumnya budidaya usaha tani kopi dilakukan dengan cara-cara tradisional, yang mana hasil produksi kopi yang diperoleh petani dirasa belum optimal.Penggunaan metode sambung mampu meningkatkan produktifitas tanaman kopi.Metode kopi sambung (entres) adalah salah satu upaya pemanfaat tanaman kopi yang sudah tidak produktif untuk meningkatkan produksi kopi. Hasil penelitian Supriadi et al. (2016), menunjukkan teknik entres kopi Robusta dengan 3 kemasan mampu mempertahankan daya tumbuh setek sebesar 55,63\%-64,01\%, hal ini didukung dengan penelitian Suhendra (2012) tentang Pendapatan Usahatani Pada Kopi Tradisional dan Kopi Sambung di Desa Lubuk Kembang, Kec. Curup Utara Kab. Rejang Lebong, menyimpulkan; rata-rata pendapatan usahatani kopi sambung sebesar Rp. 18.792.149,00/Ha/tahun dengan R/C ratio sebesar 3,85 yang menunjukkan ushatani Kopi sambung efisien. Hal ini menggunakan rekayasa fisiologi dengan cara menambal tunas tanaman atas (entres) yang lebih produktif pada batang kopi yang tidak produktif, sehingga meningkatkan hasil produksi kopi. Pemerintah Provinsi kemudian menyediakan penyambungkopi untuk para petani. Dimana Entres kopi tersebut dijual secara murah sesuai dengan kemampuan ekonomi masyarakat kalangan bawah dan menengah

Dari uraian latar belakang diatas terdapat topik yang menarik untuk dikaji lebih dalam lagi mengenai penerapan social oriented dalam penjualan entres kopi di Kebun Induk Kopi Robusta, Desa Sai, Kecamatan Pupuan. Maka tujuan dari penelitian ini adalah untuk: 1) mengetahui latar belakang melakukan penjualan penyambung kopi berdasarkan penerapan social oriented di Kebun Induk Kopi Robusta, Desa Sai, Kecamatan Pupuan; 2) mengetahui karakteristik dan keunggulan penerapan social oriented pada Kebun Induk Kopi Robusta Desa Sai, Kecamatan Pupuan; dan 3) mengetahui bagaimana penjualan penyambungkopi dapat mencapai social oriented pada aktifitas operasi Kebun Induk Kopi Robusta, Desa Sai, Kecamatan Pupuan.

\section{Metode}

Penelitian ini menggunakan pendekatan kualitatif.Penelitian kualitatif disebut interpretatif inquiry karena banyak melibatkan faktor subjektif, baik dari informan, subjek penelitian maupun peneliti itu sendiri.Penelitian ini difokuskan pada pengamatan tentang pengelolaan penjualan penyambung (entres) kopi, Kebun Induk Kopi Robusta, Desa Sai, Kecamatan Pupuan

\section{Lokasi Penelitian}

Penelitian ini dilakukan pada Kebun Induk Kopi Robusta, Desa Sai, Kecamatan Pupuan.Alasan dipilihnya lokasi ini sebagai tempat penelitian karena 
Kebun Induk Kopi Robusta tersebut melakukan penjualan entresberdasarkan social oriented untuk para petani kopi di sekitar desa tersebut.

Jenis data yang digunakan oleh penulis untuk penelitian ini adalah data kualitatif. Bogdan dan Taylor dalam Moloeng (2010) mendefinisikan penelitian kualitatif sebagai prosedur penelitian yang menghasilkan data tertulis atau lisan orang dan atau perilaku yang dapat diamati. Definisi lain dikemukan Denzin dan Licoln dalam Moloeng (2010) menyatakan bahwa penelitian kualitatif adalah penelitian yang menggunakan latar ilmiah, dengan maksud menafsirkan fenomena yang terjadi dan dilakukan dengan jalan melibatkan berbagai metode yang ada. Data dalam penelitian ini ialah data primer yaitu sumber data yang diperoleh langsung dari sumber asli (tidak melalui perantara).

\section{Metode Pengumpulan Data}

Dalam usaha memperoleh data dan keterangan guna pemecahan masalah dalam penelitian ini, penulis mengadakan penelitian secara langsung terhadap obyek penelitian. Adapun metode pengumpulan data yang dilakukan adalah dengan cara yaitu:

\section{a) Teknik Wawancara}

Wawancara adalah sebuah proses interksi komunikasi yang dilakukan oleh setidaknya dua orang, atas dasar ketersediaan dan dalam setting alamiah, dimana arah pembicaraan mengacu kepada tujuan yang telah ditetapkan dengan mengedepankan trust sebagai landasan utama dalam proses memahami (Herdiansyah, 2015).

Informan yang telah ditunjuk diwawancarai dengan memakai teknik wawancara mendalam. Wawancara akan mendalam dan berlangsung secara terarah dengan menyusun pedoman wawancara yang memuat pokok-pokok pikiran yang terkait dengan masalah yang teliti. Pengumpulan data dilakukan dengan melakukan wawancara mendalam dengan Kepala UPT Benih/Bibit Perkebunan Provinsi Bali, Staf bagian Kebun Induk Kopi Robusta.

b) Teknik Observasi

Observasi didefinisikan sebagai suatu proses melihat, mengamati, dan mencermat serta merekam perilaku secara sistematis untuk suatu tujuan tertentu (Herdiansyah, 2015)

c) Teknik Studi Dokumentasi

Teknik pengumpulan data lainnya adalah studi dokumen.Teknik in adalah pengumpulan data melalui dokumen yang tersedia yaitu berupa catatan yang tersimpan dengan baik atau didokumentasikan sebagai bahan dokumen.Dokumentasi yang digunakan peneliti dalam hal ini yaitu berupa datadata yang berhubungan pengelolaan penjualan entres kopi pada kebun Induk Kopi Robusta, Desa Sai, Kecamatan Pupuan.

\section{d) Studi kepustakaan}

Metode studi kepustakaan adalah metode penelitian yang dilakukan dalam upaya memperoleh bahan-bahan berupa teori melalui kajian buku-buku literatur, publikasi artikel ilmiah dan artikel media masa terpercaya.

\section{Metode dan Teknik Analisis Data}

Penyajian data dilakukan terhadap data yang diperoleh melalui proses wawancara, studi dokumentasi dan observasi. Data yang diperoleh melalui proses wawancara dan observasi disajikan melalui penyusunan teks naratif dalam kesatuan bentuk, keteraturan, pola-pola, penjelasan, pemaknaan, konfigurasi dan alur sebab akibat. Dalam menganalisis data kualitatif terdapat beberapa tahap yaitu melalui pengumpulan data dan reduksi data.Analisis data pada penelitian kualitatif dapat berupa kata-kata, kalimat-kalimat, atau narasi-narasi baik yang diperoleh dari wawancara mendalam maupun observasi.Kerangka metodologi penelitian dapat dilihat pada gambar 2 .

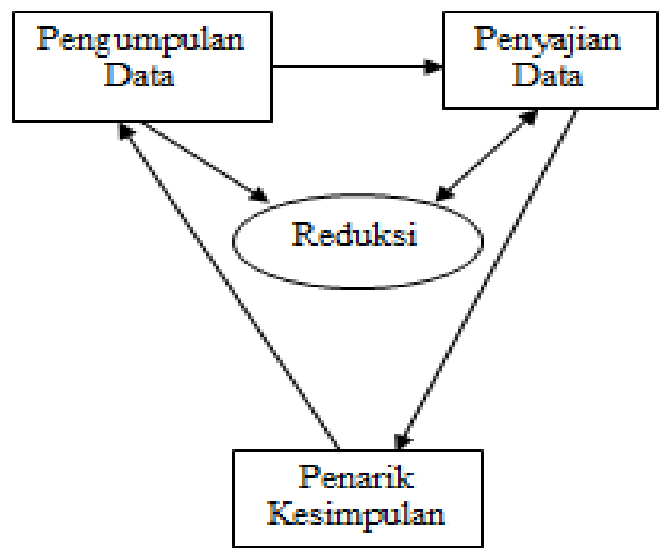

Gambar 2. Kerangka Metodologi Penelitian

\section{Hasil dan Pembahasan}

\subsection{Latar Belakang Penjualan Penyambung (Entres) Kopi Pada Kebun} Induk Kopi

Sebelumnya budidaya usaha tani kopi di Desa Sai, Kecamatan Pupuan dilakukan dengan cara-cara tradisional, yang mana hasil produksi kopi yang diperoleh petani dirasa belum optimal. Hal ini senada dengan hasil penelitian Nalurita dkk (2014) yang menyebutkan bahwa rendahnya produktivitas kopi
Indonesia disebabkan karena 95\% kopi Indonesia merupakan perkebunan rakya yang umumnya belum menggunakan bibit kopi unggul, teknik budidaya yang masih sederhana serta lambat melakukan peremajaan tanaman, minimnya sarana dan prasarana pendukung mengakibatkan rendahnya mutu kopi Indonesia.

Penelitian lainnya dari Zakaria dkk (2017) menunjukkan beberapa kelemahan pada usaha tani kopi arabika di Desa Suntenjaya Jawa Barat, yaitu:

a. Kekurangan modal pengembangan usaha

b. Hasil produksi yang belum optimal karena kualitas bibit yang belum bersertifikat.

c. Kelompok tani yang kurang diberdayakan dan belum optimalnya kegiatan belajar (pelatihan).

d. Sulit mendapatkan bibit kopi berkualitas.

Salah satu hal yang diharapkan oleh Zakaria, dkk setelah penelitian tersebut adalah adanya penyediaan bibit kopi arabika yang bersertifikat dengan varietas unggul, dan pembinaan dari pemerintah dalam bentuk pendidikan dan pelatihan dalam upaya meningkatkan mutu sehingga dihasilkan produk dengan nilai jual yang lebih tinggi.

Kebun Induk Kopi Robusta dibangun pada tahun 1973 yang berlokasi di Desa Sai, Kecamatan Pupuan Kabupaten Tabanan dengan jarak 59 km kearah barat dari Kota Denpasar. Kebun Induk Kopi Robusta seluas 13,95 ha dimiliki oleh Pemerintah Provinsi Bali dan dikelola oleh Dinas Perkebunan Provinsi Bali melalui UPTD Benih/Bibit. Kebun ini merupakan kebun sumber entres bagi pengembangan budidaya kopi robusta. Penggunaan metode sambung telah mampu meningkatkan produktifitas tanaman kopi. Metode kopi sambung (entres) adalah salah satu upaya pemanfaat tanaman kopi yang sudah tidak produktif untuk meningkatkan produksi kopi. Seperti dijelaskan langsung oleh staf di Kebun Induk Kopi Robusta, Ibu Seri Yustini:

"Sebelumnya petani kopi di desa ini hanya memanen kopi liar. Sehingga hasil panen mereka terbatas dan kurang berkualitas. Setelah adanya kebun induk kopi ini, para petani mendapatkan pelatihan dan pengetahuan mengenai entres. Petani juga lebih mudah mendapatkan entres ini, sehingga produksi kopinya meningkat dan berkualitas. Setiap tahun, untuk produksi kopi Oce/kopi beras hasil petani di desa ini dilelang oleh pihak provinsi. Harganya dipatok dengan harga paling tinggi."

Pernyataan tersebut selaras dengan penelitian Suhendra et al. (2012) yang menunjukkan rata-rata produksi kopi beras secara tradisional sebesar 953 $\mathrm{Kg} / \mathrm{Ha} /$ tahun, sedangkan produksi kopi beras dengan teknik sambung (entres) mampu menghasilkan rata-rata $2.281 \mathrm{Kg} / \mathrm{Ha} /$ tahun. Hal ini menggunakan rekayasa fisiologi dengan cara menambal tunas tanaman atas (entres) yang lebih produktif pada batang kopi yang tidak produktif, sehingga meningkatkan hasil produksi kopi. Pemerintah Provinsi kemudian menyediakan penyambungkopi untuk para petani. Dimana entres kopi tersebut dijual secara murah sesuai dengan kemampuan ekonomi masyarakat kalangan bawah dan menengah.

Kebun Induk Kopi Robusta di Desa Sai juga dijadikan sebagai tempat pelatihan untuk para petani yang ingin memulai usahanya dibidang pertanian kopi. Harga yang murah juga merupakan salah satu program yang dilakukan di Kebun Induk Kopi Robusta, mengingat kondisi masyarakat desa yang pada umumnya memiliki ekonomi yang masih di bawah rata-rata. Berdasarkan hasil wawancara, berikut dapat diketahui tugas dan fungsi Kebun Induk Kopi Robusta di Desa Sai, Kecamatan Pupuan Kabupaten Tabanan yaitu:

1. Melakukan pemeliharaan kebun secara intensif dan sekaligus menjaga peresapan air dan penahan erosi pada dataran tinggi serta pelestarian plasma nutfah klon kopi robusta di Bali.

2. Melakukan peningkatan produksi dan sebagai sumber penyedia benih dan bibit serta entres untuk batang atas dan bawah kopi robusta yang bermutu dan unggul, serta untuk menunjang peremajaan dan rehabilitasi kopi.

3. Menyediakan sarana dan prasarana pelatihan serta sumber informasi bagi petugas perkebunan dan petani perkebunan, dalam rangka meningkatkan pengetahuan dan keterampilan teknis perkopian.

4. Melakukan upaya peningkatan Pendapatan Asli Daerah (PAD) bagi daerah Bali.

Sejauh ini, Kebun Induk Kopi Robusta sangat memiliki peran besar bagi petani di seputaran Desa Sai. Salah satunya adalah program penyediaan entres kopi berbasis social oriented yang sangat diperlukan dan dimanfaatkan oleh para petani. Kebun induk kopi robusta sendiri tidak menyediakan bibit jadi, hanya menyediakan entres (penyambung) kopi. Maka dari ini sisi positif lainnya yang dapat dirasakan adalah ketika sebagian besar petani yang merevitalisasi tanaman kopinya. Para petani termotifasi untuk belajar membibit tanaman kopi sendiri berbekal ilmu yang telah didapatkan selama pelatihan.

\subsection{Karakteristik dan Keunggulan Penerapan Social Oriented Pada Kebun Induk Kopi}

Kebun Induk Kopi Robusta di Desa Sai, Kecamatan Pupuan Kabupaten Tabanan melakukan kegiatannya dengan berorientasi sosial. Hal ini ditunjukkan dengan penjualan produk berupa entres kopi dijual dengan harga relatif murah kepada petani rakyat di Desa Sai, yang juga mayoritas merupakan penduduk dengan kondisi ekonomi menengah kebawah. Dan dijual lebih mahal kepada masyarakat luas lainnya. Dengan adanya Kebun Induk Kopi Robusta sendiri memudahkan masyarakat untuk mencari entres kopi guna mentransformasi kopi menjadi bibit yang unggul. Neacşu(2018), melakukan penelitian tentang kualitas manajemen pada pasar kopi menyatakan bahwa penggunaan optimal sumber daya merupakan salah satu bentuk kegiatan guna mencapai tujuan utama, kebun induk kopi robusta mengeksekusi dalam bentuk pelatihan dan penyediaan entres 
bagi petani kopi guna meningkatkan kualitas komoditi kopi di Desa Sai. Seperti dijelaskan langsung oleh staf di kebun induk kopi robusta, Ibu Seri Yustini :

"Keberhasilan petani tidak bisa dinilai dengan uang, coba sebelum ada kebun induk kebanyakan masyarakat masih memiliki kopi lokal, sedangkan tanggungan hidup petani yang banyak dibandingkan dengan pendapatan mereka yang sedikit dari kopi lokal yang mereka hasilkan. Namun setelah ada kebun induk, keberhasilan petani dibidang kopi sudah meningkat drastis dan luar biasa, karena adanya klon-klon baru entres kopi yang disediakan oleh Kebun Induk guna menciptakan bibit kopi yang berkualitas."

Berbeda dengan perusahaan swasta yang berfokus pada keuntungan (profit oriented), Kebun Induk Kopi Robusta ini berfokus kepada sosial (social oriented) yang mana kehadirannya bertujuan untuk meningkatkan kehidupan sosial masyarakat. Adanya penjualan entres kopi yang berfokus pada sosial ini dapat memberikan kemudahan kepada masyarakat Desa Sai untuk dapat meningkatkan kesejahteraan hidupnya melalui kegiatan pertanian kopi.

\subsection{Penjualan EntresKopi BerbasisSocial oriented pada Aktifitas Operasi}

\section{Kebun Induk Kopi Robusta}

Hasil penelitian terdahulu dari Titisari (2016) menunjukkan bahwa petani kopi rakyat di Daerah Silo merupakan penghasil kopi rakyat terbesar di Kabupaten Jember yang mana proses perolehan bibit sampai penjualan belum dilakukan sistem kemitraan yang menguntungkan petani. Penjualan ialah proses sosial manajerial dimana individu dan kelompok mendapatkan apa yang mereka butuhkan dan inginkan, menciptakan, menawarkan dan menukarkan produk yang bernilai dengan pihak lain (Kotler, 2009). Sedangkan menurut Asri (1991), Penjualan adalah suatu usaha yang terpadu untuk mengembangkan rencanarencana strategis yang diarahkan pada usaha pemuasan kebutuhan dan keinginan pemebeli, guna mendapatkan penjualan yang menghasilkan laba. Penjualan dilakukan dengan mencari keuntungan bagi perusahaan itu sendiri (profit oriented). Namun ada juga penjualan yang tidak berfokus pada laba, akan tetapi berfokus dalam membantu konsumennya (social oriented). Seperti yang di ungkapkan Ibu Seri, selaku pegawai di Kebun Induk Robusta, berikut:

"Kebun induk robusta itu sendiri memang kebun milik pemerintah. Fungsinya sendiri sebagai penyedia dan pelatihan bukan mencari keuntungan (kegiatan berbasis social oriented). Biasanya biaya pengeluarannya akan lebih besar dari pemasukannya. Karena disini untuk penjualan entres sendiri dibagi menjadi 2 yaitu untuk proyek/kelompok dan petani rakyat. Untuk petani rakyat sendiri yang membeli entres akan diberi subsidi. Sehingga masyarakat petani dengan mudah dan terjangkau mendapatkannya".

Pernyataan tersebut selaras dengan penelitian Budidarsono dan Wijaya (2003), praktik budidaya kopi multistrata di Sumberjaya secara finansial dan ekonomis ternyata mampu memberikan keuntungan bagipetani dan sekaligus menyediakan lapangan pekerjaan di pedesaan secara berkelanjutan. Jadi kegiatan kebun induk kopi robusta lebih berfokus pada dampak ekonomi (economic benefit) yang bertujuan meningkatkan pertumbuhan ekonomi petani kopi, dibandingkan memperoleh keuntungan secara finansial (financial benefit).Tujuan dari social oriented pada aktifitas operasi Kebun Induk Kopi Robusta adalah sejalan dengan tujuan sosial untuk masyarakat khususnya petani kopi. Bisa dilihat pada beberapa tugas dan fungsi dari kebun induk itu sendiri sebagai penyedia entres dan sebagai tempat pelatihan. Maka dari penelitian ini dapat diambil kesimpulan bahwa tercapainya tujuan sosial (social oriented) dan manfaat yang dirasakan masyarakat akan adanya Kebun Induk Kopi Robusta dalam penyedia sekaligus penjual entres kopi berkualitas bagi masyarakat desa seputaran Desa Sai.

Kehadiran pemerintah melalui program yang bersifat social oriented sangat diperlukan dalam penyediaan benih bibit kopi dengan harga pasar sesuai dengan kemampuan ekonomi masyarakat Desa Sai yang tergolong rendah. Untuk entres kopi yang dijual, harganya dibedakan menjadi dua yaitu khusus petani kopi rakyat dengan harga Rp250/ruas dan kegiatan proyek/Lembaga Ekonomi Masyarakat dengan harga Rp750/ruas. Harga tersebut dibedakan karena pemerintah memberikan subsidi kepada masyarakat petani kopi rakyat sebagai tujuan untuk mensejahterakan masyarakat petani kopi. Subsidi inilah yang merupakan program social oriented yang telah diterapkan pada penjualan entres kopi. Harga yang telah ditentukan tersebut tidak semata-mata dibuat begitu saja, akan tetapi sudah disesuaikan dengan peraturan perundang-undangan yang berlaku. "Beberapa desa di seputaran Kecamatan Pupuan yang sudah membentuk LEM (Lembaga Ekonomi Masyarakat). LEM ini tersebar di beberapa Desa seperti: (1) Desa Pujungan, (2) Desa Kebon, (3) Desa Batungsel, (4) Desa Munduk Temu, (5) Desa Pajahan. Untuk LEM yang sudah berbadan hukum seperti LEM di Desa Pajahan, mungkin kelompok tersebut bisa menjual entres ke masyarakat.Akan tetapi dalam hal ini jika kebutuhan anggota sudah terpenuhi."

Berdasarkan pernyataan Bapak Mustiki selaku staf di Kebun Induk tersebut diketahui untuk kelompok yang membeli entres tersebut dikenakan harga yang lebih mahal dikarenakan entres yang dibudidayakan bisa di jual oleh Lembaga Ekonomi Masyarakat yang sudah berbadan hukum tersebut untuk keuntungan kelompok dengan menjual langsung ke masyarakat di seputaran desa tersebut selain menjual ke anggotanya.Sehingga dengan adanya kebun induk saja, bisa sebagai penyangga dalam meningkatkan ekonomi masyarakat yang notabene sebagai petani kopi. Sistem Penjualan Entres di Kebun Induk Kopi Robusta dapat dilihat pada gambar 3.

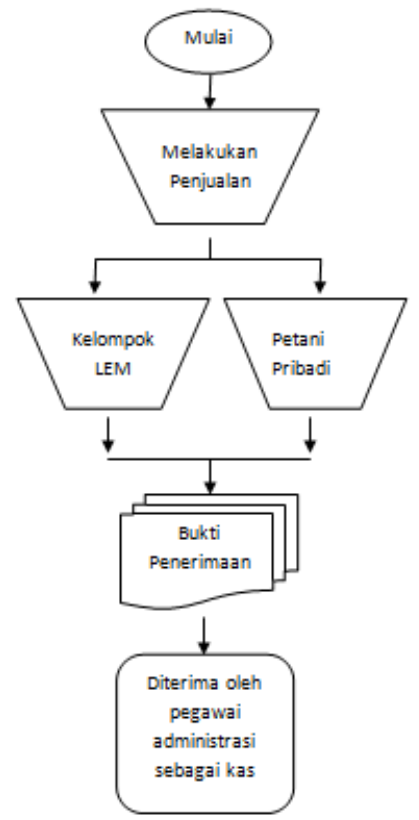

Gambar 3.Sistem Penjualan Entres di Kebun Induk Kopi Robusta

\section{Simpulan}

Kesimpulan penulis yang dapat diambil dari pembahasan penelitian ini adalah sebagai berikut :

1. Diketahui bahwa latar belakang penjualan entres kopi pada kebun induk kopi adalah untuk menyediakan entres kopi yang digunakan oleh petani dalam merevitalisasi tanaman kopinya yang sudah tidak produktif. Selain itu juga diadakan pelatihan-pelatihan untuk para petani kopi di kebun induk kopi.

2. Karakteristik dan keunggulan penerapan social oriented pada kebun induk kopi adalah adanya fokus kepada sosial (social oriented) yang mana kehadirannya bertujuan untuk meningkatkan kehidupan sosia masyarakat. Adanya penjualan entres kopi yang berfokus pada sosial ini dapat memberikan kemudahan kepada masyarakat Desa Sai untuk dapat meningkatkan kesejahteraan hidupnya melalui kegiatan pertanian kopi.

3. Penjualan entres kopi berbasis social oriented pada aktifitas operasi kebun induk kopi robusta. Untuk entres kopi yang dijual, harganya dibedakan menjadi dua yaitu khusus petani kopi rakyat dengan harga Rp250/ruas dan kegiatan proyek/Lembaga Ekonomi Masyarakat dengan harga Rp750/ruas. Harga tersebut dibedakan karena pemerintah memberikan subsidi kepada masyarakat petani kopi rakyat sebagai tujuan untuk mensejahterakan masyarakat petani kopi. Subsidi inilah yang merupakan program social oriented yang telah diterapkan pada penjualan entres kopi.

Pustaka

Ariyanti, Widya, Any Suryantini, dan Jamhari. 2019. Usaha Tani Kopi Robusta di Kabupaten Tanggamus: Kajian Strategi Pengembangan Agrobisnis. Jurnal Kawistara Vol 9, No. 2, 22 Agustus 2019, hal 179-191.

Asri, Marwan. 1991. Marketing. Yogyakarta: UPP-AMP YKPN

BPS. 2019. Statistik Kopi Indonesia 2018. Jakarta

Budidarsono, S. Wijaya, K. 2004. Praktek Konservasi Dalam Budidaya Kopi Robusta dan Keuntungan Petani.World Agroforesstry Centre.ICRAF SE Asia. Bogor

Diantini, Adik. 2007. Diskriminasi Harga Pada Wisatawan Asing untuk Meningkatkan Laba Perusahaan Dalam Perspektif Hukum Karma Phala.Jurnal Imiah Akuntansi. 23-24

Herdiansyah, Haris, (2015), Wawancara, Observasi, dan Focus Groups Sebagai Instrumen Penggalian Data Kualitatif, PT. Rajadrafindo Persada, Depok.

Karo, Hosana Sri Arta Br. 2009. Analisis Usahatani Kopi di Kecamatan Simpang Empat Kabupaten Karo. Skripsi Fakultas Pertanian Universitas Sumatera Utara. Medan.

Kemenperin. 2012. Penurunan Produksi Pengaruhi Ekspor Kopi Indonesia $\begin{array}{llll}\text { Diakses } & \text { tanggal } & 20 & \text { Mei }\end{array}$ https://kemenperin.go.id/artikel/2918/Penurunan Produksi Pengaruhi-

Kementan.2020. Sektor Pertanian Kontribusi Wujudkan NawaCita. Diakses

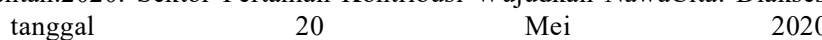
.https://www.pertanian.go.id/home/?show=news\&act=view\&id=3321

Kotler dan Keller. 2009. Manajemen Pemasaran. Jilid 1.Edisi ke 13. Jakarta: Erlangga.

Moleong, L. J. 2010. Metodologi Penelitian Kualitatif, Bandung: Remaja Rosda karya. 
Nalurita, Sari, Ratna Winandi Asmarantaka dan Siti Jahroh. 2014. Analisis Dayasaing dan Strategi Pengembangan Agribisnis Kopi Indonesia. Jurna Agribisnis Indonesia (Vol 2 No 1, Juni 2014); halaman 63-74

Neacșu, Andreea N. 2018. Quality Management on The Coffee Market. Bulletin of the Transilvania University of Braşov.Series V: Economic Sciences • Vol. 11 (60) No. 1 - 2018 (109-118). Rumania

Nopriyandi, Rexsi dan Haryadi. 2017. Analisis ekspor kopi Indonesia. Jurnal Paradigma Ekonomika Vol. 12. No. 1, Januari-Juni 2017 ISSN: 20851960.

Permatasari, Devi.2014. Analisis Pendapatan Usahatani Gula Tumbuh (Kasus Kecamatan Dawe Kabupaten Kudus).Skripsi Fakultas Ekonomi dan Bisnis Universitas Diponegoro. Semarang.

Suhendra, Dori, Muhammad Nurung, dan Reswita. 2012. Analisis Pendapatan Usahatani Pada Kopi Tradisional dan Kopi Sambung di desa lubuk Kembang, Kec. Curup Utara, Kab. Rejang Lebong. AGRISEP. Vol 11, No 1, Maret 2012: 61-68

Supriadi, Handi, Dewi Nur rokhmah, dan Saefudin. 2016. Teknologi Pengemasan Entres Selama Distribusi untuk Mempertahankan Daya Tumbuh Setek Kopi Robusta.JTIDP. Vol 3, No 3, November 2016: 135 140

Titisari, Purnamie. 2016. Alternatif Tindakan Meningkatkan Pendapaan Petani Kopi Rakyat Kabupaten. Prosiding Dinamika Global: Rebranding Keuanggulan Kompetitif Berbasis Kearifan Lokal. ISBN 978-602-60569$2-4$.

Zakaria, Akhmad, Pingkan Aditiawati, dan Mia Rosmiati. 2017. Strategi Pengembangan Kopi Arabika (Kasus Pada Petani Kopi di Desa Suntenjaya Kecamatan Lembang Kabupaten Bandung Barat, Provinsi Jawa Barat). Jurnal Sosioteknologi. Vol 16, No 3, Desember 2017 